\title{
Assessment of Land Surface Temperature and LULC Changes and the Antecedent Flood Hazard in Ibadan, Nigeria
}

\author{
Adetoro $0^{1 *}$ and Salami A ${ }^{2}$ \\ ${ }^{1}$ Space Applications and Environmental Science Laboratory, Institute of Ecology and \\ Environmental Studies, Obafemi Awolowo University, Nigeria \\ ${ }^{2}$ The Technical University, Ibadan, Nigeria
}

*Corresponding author: Olusola Adetoro, Space Applications and Environmental Science Laboratory, Institute of Ecology and Environmental Studies, Obafemi Awolowo University, Nigeria, Tel: +2348037141425; Email: omoige@gmail.com

\section{Abstract}

The study expounds Space Technology usefulness in flood vulnerability assessment. Landsat images for 1972, 1984, 2000, 2013 and ASTER DEM for the area was used to examine LULC spatial dynamics and land surface temperature while the MCDA was used for the flood vulnerability assessment in the urban watershed. Results show that the LULC categories that shows increase are built up and Light vegetation which amounted to 12628.6 ha $(4.7 \%)$ and 53867.5 (19.8\%) $5,546.2$ ha $(1.9 \%)$ respectively. There is a pattern of increase in vulnerability on built up, Light vegetation, bare soil and water body accounting for 8993.60 ha (94.77\%), 2364.18 ha (9.73\%), 14121.80 ha (81.05\%), 419 (77.59) for year 1972 and 26700.57 ha (57.16\%), 9560.65 ha (9.16\%), 3697.19 (83.68), 1.29 ha (0.78\%) for the year 2013 respectively. The LST result presented the highest LST range from 2013, 2000, 1984 accounted for 34-410c, 24-320c, and 16-310c respectively and the lowest temperature range is $3-16{ }^{\circ} \mathrm{C}, 10-20{ }^{\circ} \mathrm{C}$ and $24-31{ }^{\circ} \mathrm{C}$ in 1984,2000 and 2013 respectively. This study established continuously increase in LUC due to uncontrolled clearance of land cover for urban expansion which has exposed the surface area to increased temperature and aggravates flood risk and other environmental problems in the urban watershed.

Keywords: Land Use; Flood; Land surface Temperature; Watershed; Landsat; MCDA; Vulnerability; Space Technology

\section{Introduction}

In the wake of suburbanization many issues have risen as people have built more and more standing structures that alter the landscape. One of the main issues with urban development is the flooding that occurs in unwanted places. Flood is rated among the world's most frequent, recurring, widespread, catastrophic types of disaster in the world [1-2]. Aderogba [3] identified that the flood consequences around the globe are becoming too frequent and threat to sustainable development in human settlements because of rapid urbanization resulting in land use change, inadequate provision and maintenance of drainage systems, the location of people on marginal sites, and the physical characteristics of an area [4] which makes Ibadan not an exception. The regular occurrence of flood has become a periodical challenge in Ibadan [5]. This problem is predominant in 


\section{Journal of Ecology \& Natural Resources}

Nigerian urban areas that are under strong environmental degradation due to population pressure. It was noted that within the year 2001, 17 flood events were recorded with more than 2,372 fatalities and more than $\$ 3.5$ billion in economic losses in the world [6]. Akintola [7] also described flooding as one of the environmental hazards which affects lives and destroy properties recording the death of over 20,000 lives per year.

In Nigeria, flooding is a common experience in most parts of the country. The causes are mainly from three major factors namely: heavy downpour, overflow of drainage channels and emergency release of water from dams. It is recognised as a major calamity which has forced millions of people from their homes, destroyed businesses, polluted water resources and increased the risk of diseases [8-12] especially in the urban areas where it is becoming an ecological menace [13]. In 2012, Ilorin, Anambra, Delta, Rivers states experienced a severe flood disaster due to the Dam opening and over flow from Cameroun which claimed properties and lives. Heavy rainfall for considerably longer periods often built up excess water beyond which percolation can accommodate [14]. As a result, the water level begins to rise and flood flows in the direction of slopes and into neighbouring depressions. This flood occurrence has caused land degradation in some parts of the country which could be attributed to land use and cover change associated with human activities and increase in flood risk $[15,16]$. Adeaga, also argued that continuous growth of cities calls for better understanding of the functional relationship between urbanization and hydrological responses since urbanization leads to increase in total impervious surfaces and other land surface parameters. Land surface as described by Adeaga 0, Melesse AM [4,17], affects the portioning of water and energy fluxes, which in turn changes the state of the surface. Ikuhoria, Yesuf, Enaruvbe and Ige-Olumide [14], posited that increase in human activity downstream of rivers result in greater flood damage; floods are also increasing in size and frequency due to human activities upstream section of river.

Diverse studies on flood have been carried out but identified that they are too quantitative in nature with limited emphasis on the use of geospatial techniques for such study [18-23]. Few studies identified level of flood vulnerability and risk that the urban dwellers are exposed to Aderogba KA, Schmugge T $[3,24]$ and few had less geospatial considerations on integrated approach for flood vulnerability which are needed to help users understand the spatial dimensions mostly in urban settings [25]. This study examines the land surface parameters aggravating flood vulnerability using geospatial techniques.

\section{Results}

\section{Land Use Land Cover Change Detection}

Nature of change from 1972-2013: Table 1 shows the progression of change for 1972 to 2013. There was a steady increase from the year 1972 (9.4\%) - 2013 $(40.2 \%)$ in the built-up area. However, the year 2000 $(15.3 \%)$ experienced a minute transitional change in built up areas when compared with the that of built up changes in the other three years (1972, 1984 and 2013) which was because of the flooding that happened in the 80s and the 90s has reported and analysed from the field survey. The water bodies were of the maximum in the year 1972 which drastically reduced in 1984 and steadily reducing till 2013. This was noticed to have been because of people's encroachment to water bodies, which make those in the area vulnerable and at risk to flooding.

There was increment in the size of the vegetated areas of the study area from 1972 (8.9\%) - 2013 (41.3\%) which resulted from deforestation. The forested areas were inversely proportional to the vegetated areas as there was decrement from 1972 (72.6\%) - 2013 (14.3\%). This showed that the tree cover which reduced the rate of infiltration to the ground and thereby preventing flooding has experienced drastic change due to factors mainly ineffective land use practices, increase in level of immigration and population growth and increase in the demand for more facilities and amenities as identified from the field survey and this could be attributed to continual removal of forest to cater for agricultural purposes and urbanization.

\begin{tabular}{|c|c|c|c|c|c|c|c|c|}
\hline LULC Type & 1972 Area(ha) & \% & 1984 Area(ha) & \% & 2000 Area(ha) & \% & 2013 Area(ha) & \% \\
\hline Builtup & 25681.1 & 9.4 & 38309.7 & 14.1 & 41568.4 & 15.3 & 109356.4 & 40.2 \\
\hline Water & 7562.5 & 2.8 & 408.8 & 0.2 & 380.4 & 0.1 & 293.8 & 0.1 \\
\hline Dense vegetation & 197069.9 & 72.4 & 140387.2 & 51.6 & 37947.6 & 13.9 & 39031.1 & 14.3 \\
\hline Light vegetation & 24335.5 & 8.9 & 78203.0 & 28.7 & 103498.8 & 38.1 & 112356.8 & 41.3 \\
\hline Baresoil & 17468.4 & 6.4 & 14809.0 & 5.4 & 88722.1 & 32.6 & 11079.4 & 4.1 \\
\hline Total & 272117.4 & 100 & 272117.4 & 100 & 272117.4 & 100 & 272117.4 & 100 \\
\hline
\end{tabular}

Table 1: Area statistics and percentage of the LULC progression change from 1972-2013. 
The bare land of the study area was gradually reducing in size from 1972 (6.4\%) - 1984 (5.4\%) resulting from urbanization. Unfortunately, there was a sudden increase in its size in 2000 (32.6\%) which resulted from the flooding that also negatively affected the built up areas. This flooding also negatively affected the forested areas by removing the tree covers and turning them to vegetated areas thereby increasing their size in that year.

Nature of change for each land use/Land cover from 1972-2013: It was observed that there is a pattern of increase on built up areas from the year 1972 (11.9\%) 2013 (50.9\%) in the built-up area of the study area. The water bodies were of the maximum in the year 1972 which drastically reduced in 1984 and steadily reducing till 2013. This was noticed to have been resulted from people's encroachment to water bodies, which make those in the area vulnerable and at risk to flooding.

There was an increment in the size of the vegetated areas of the study area from 1972 (7.6\%) - 2013 (35.3\%) which resulted from deforestation. The forested areas were inversely proportional to the vegetated areas as there was decrement from 1972 (47.6\%) - 2013 (9.4\%). The bare land of the study area was gradually reducing in size from 1972 (13.2\%) - 1984 (8.4\%) resulting from urbanization. Unfortunately, there was a sudden increase in its size in 2000 (67.07\%) which resulted from the flooding that also negatively affected the built-up areas (Table 2).

\begin{tabular}{|c|c|c|c|c|c|c|c|c|c|c|}
\hline LULC type & \multicolumn{2}{|c|}{ Built up } & \multicolumn{2}{c|}{ Water } & \multicolumn{2}{c|}{ Dense vegetation } & \multicolumn{2}{c|}{ Light vegetation } & \multicolumn{2}{c|}{ Baresoil/Land } \\
\hline & Area(ha) & $\%$ & Area(ha) & $\%$ & Area(ha) & $\%$ & Area(ha) & $\%$ & Area(ha) & $\%$ \\
\hline 1972 & 25681.1 & 13.1 & 7562.5 & 87.5 & 197069.9 & 47.6 & 24335.5 & 7.2 & 17468.4 & 13.2 \\
\hline 1984 & 38309.7 & 19.5 & 408.8 & 4.7 & 40387.2 & 33.9 & 78203 & 23.2 & 14809 & 11.2 \\
\hline 2000 & 41568.4 & 15.3 & 380.41 & 4.4 & 37947.6 & 9.2 & 103498.8 & 38.1 & 88722.1 & 67.2 \\
\hline 2013 & 109356.4 & 55.8 & 293.8 & 3.4 & 39031.1 & 9.4 & 112356.8 & 33.3 & 11079.4 & 8.4 \\
\hline Total (\%) & & 100 & & 100 & & 100 & & 100 & & 100 \\
\hline
\end{tabular}

Table 2: Area statistics and percentage of the each LULC units' progression change from 1972-2013.

\section{Multi Criteria Decision Analysis for Flood Vulnerability}

The various criterion layer for the flood vulnerability namely: land use, drainage density, slope, elevation, and soil type were integrated. These data were all rasterized and re-sampled to $30 \mathrm{~m}$ pixel size to allow compatibility during the weighted overlay processes. A pair wise comparison was used to assess and weights of the criteria in Table 3.

\begin{tabular}{|c|c|c|c|c|c|c|c|}
\hline Factors & Drainage Density & Slope & Soil & Elevation & Land Use & Eigen vector & Weight *100 \\
\hline Drainage & $\mathbf{1}$ & $\mathbf{2}$ & $\mathbf{3}$ & $\mathbf{4}$ & $\mathbf{7}$ & $\mathbf{0 . 4 5 8}$ & $\mathbf{4 5}$ \\
\hline Slope & $\mathbf{0 . 5}$ & $\mathbf{1}$ & $\mathbf{3}$ & $\mathbf{4}$ & $\mathbf{6}$ & $\mathbf{0 . 3 3 6}$ & $\mathbf{3 3}$ \\
\hline Soil & $\mathbf{0 . 3 3 3 3}$ & $\mathbf{0 . 3 3 3 3}$ & $\mathbf{1}$ & $\mathbf{2}$ & $\mathbf{3}$ & $\mathbf{0 . 1 5 1}$ & $\mathbf{1 5}$ \\
\hline Elevation & $\mathbf{0 . 2 5}$ & $\mathbf{0 . 2 5}$ & $\mathbf{0 . 5}$ & $\mathbf{1}$ & $\mathbf{2}$ & $\mathbf{0 . 0 9 4}$ & $\mathbf{9}$ \\
\hline Land Use & 0.142857 & 0.16667 & 0.3333 & $\mathbf{0 . 5}$ & $\mathbf{1}$ & $\mathbf{0 . 0 5 4}$ & $\mathbf{5}$ \\
\hline
\end{tabular}

Table 3: Pair wise comparison of factors causing flooding.

$\mathrm{CI}=0.018$

CR $0.018 / 1.12=0.016$

$\mathrm{CR}$ is less than 0.1 thus this makes the judgments consistent.

The pair wise comparisons results indicated that drainage is a major contributor of flooding in the watershed with $45 \%$ weight of all the factors while Slope, soil, elevation, and LULC of the area are 33\%, 15\%, 9\%, $5 \%$ are weight of other factors respectively. Using the weights generated the criterion layers were introduced into GIS and using The Weighted overlay technique in ArcGIS tools, all the criterion layers were combined to produce a final flood hazard vulnerability map per catchment (see figure $2 \mathrm{a}, 2 \mathrm{~b}, 2 \mathrm{c} \& 2 \mathrm{~d}$ ) for the different years. Multi-criteria technique was used in combining biophysical factors of flooding deduced the spatial extent of areas prone to the hazard and are vulnerable to flood in the watershed.

Flood vulnerability from 1972 -2013: The Vulnerability of the catchment to flood shows that in 1972, the total 
area vulnerable to flooding is lower when compared to 1984, while in 1984 to 2000 it is higher and in 2000-2013 there was an increase. Different catchment in the watershed is experiencing all, one of two the three vulnerability levels as presented in the flood vulnerability maps.

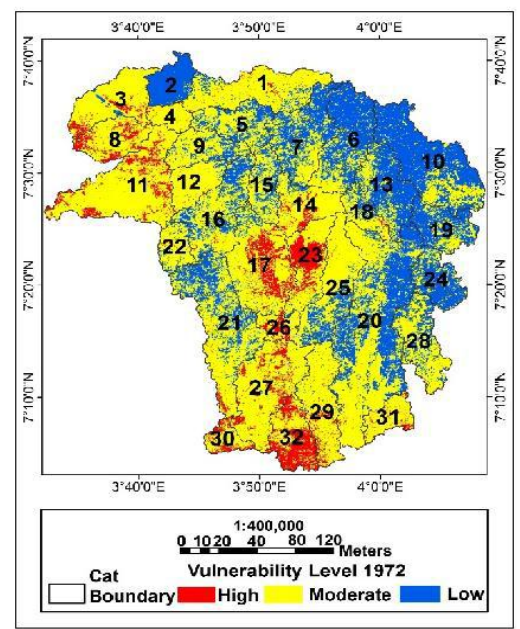

(a)

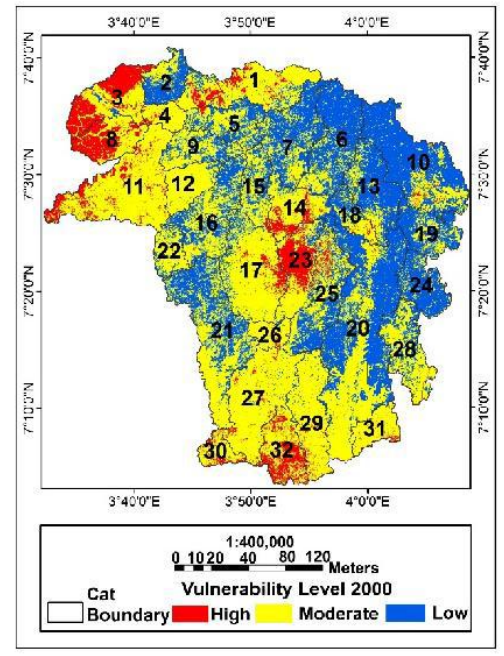

(c)

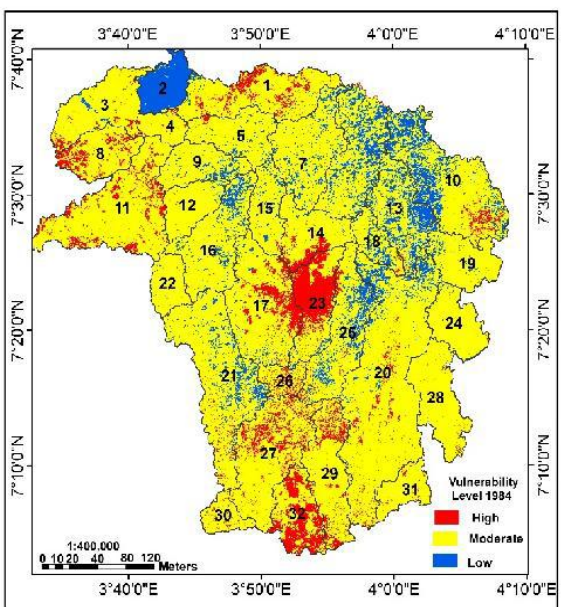

(b)

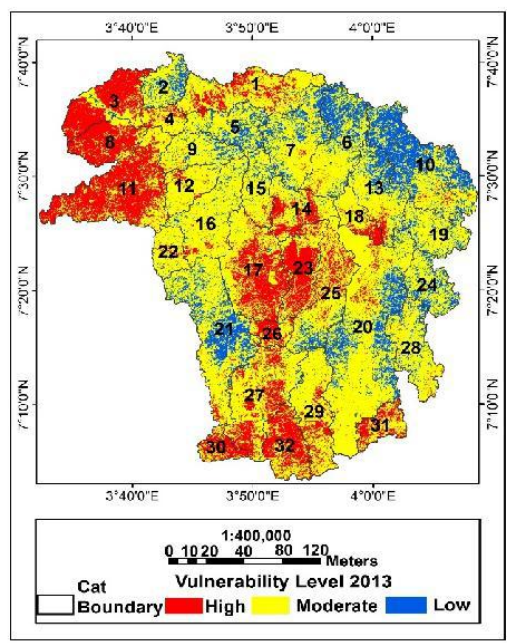

(d)

Figure 1: (a) Flood Hazard/Vulnerability in each catchment for the year 1972 (b) Flood Hazard/ Vulnerability catchment year 1984 (c) Flood Hazard/Vulnerability in each catchment for the year 2000 (d) Flood Hazard/Vulnerability in each catchment for the year 2013.

\section{Derived Land Surface Temperature (LST)}

The surface temperature was mathematically derived and computed in tabular and map forms which identified the land uses/land covers information from the each of the steps carried out.

\section{Top atmospheric reflectance spectral radiation} (ToAr): The spectral radiation of Top of Atmospheric reflectance (ToAr) was estimated and this describes the highest reflectance value of 14.302 for $1984,12.88$ for 2000 and 11.39 for 2013 which implies a decline in the rate of reflectance while the lowest value is $0.5,6.9$ and 8.9 for 1984, 2000 and 2013 respectively implying the increase in lower values (Table 5). This implies that features in the category of 0 reflectance in 1984 has gain reflectance value of 6.91 in 2000 and 8.94 in 2013 and values with higher reflectance decreased. 


\section{Journal of Ecology \& Natural Resources}

Top of Atmospheric/At-Satellite Brightness Temperature: The highest temperature which is given in Kelvin is 334.132 (2013) other values for 2000 and 1984 are 323.564 and 311.978 respectively and this shows an increase while the lowest brightness temperature is 178.183 in same 2013. Then, form this analysis it could be concluded that the lower the spectral reflectance the higher the ToA brightness temperature when compared (Table 6).

Estimated Emissivity using NDVI: The Emissivity values were estimated using the Computed Normalized Difference Vegetation index (NDVI) values. The emissivity value estimated for the three different years (Table 7) shows that values for the different land uses considered in this study.

The values for Built up, Water, Dense vegetation, Light Vegetation and Bare land/soil are 0.912, 0.989, 0.967, 0.957 and 0.989 respectively.

\begin{tabular}{|c|c|c|c|}
\hline (ToAr) & $\mathbf{1 9 8 4}$ & $\mathbf{2 0 0 0}$ & $\mathbf{2 0 1 3}$ \\
\hline HIGH & 14.302 & 12.88 & 11.39 \\
\hline LOW & 0.5 & 6.9 & 8.9 \\
\hline
\end{tabular}

Table 4: Top Atmospheric Reflectance (ToAr) (1984 2013).

\begin{tabular}{|c|c|c|c|}
\hline (ToAr) & $\mathbf{1 9 8 4}$ & $\mathbf{2 0 0 0}$ & $\mathbf{2 0 1 3}$ \\
\hline HIGH & 311.978 & 323.564 & 334.132 \\
\hline LOW & 296.355 & 280.201 & 178.183 \\
\hline
\end{tabular}

Table 5: Top of Atmospheric/At-Satellite Brightness Temperature 1984.

\begin{tabular}{|c|c|}
\hline Classes & Emissivity 1984, 2000, \\
& $\mathbf{2 0 1 3}$ \\
\hline Built Up & 0.912 \\
\hline Water & 0.989 \\
\hline Dense Vegetation & 0.967 \\
\hline Light Vegetation & 0.957 \\
\hline Bareland/Soil & 0.896 \\
\hline
\end{tabular}

Table 6: Estimated Emissivity Value 1984-2013.

Land surface temperature (LST) estimated and converted to celsius $\left({ }^{\circ} \mathbf{C}\right)$ : Furthermore, there was an integration of processes and analysis for deriving the surface temperature (Figures 8a-8c). The land surface temperature was derived in kelvin which was converted to Celsius using relevant formula. The LST result presented the highest LST range from 2013, 2000, 1984 accounted for 34-410c, 24-320c, and 16-310c respectively and the lowest temperature range is $3-16^{\circ} \mathrm{C}, 10-20^{\circ} \mathrm{C}$ and $24-31^{\circ} \mathrm{C}$ in 1984,2000 and 2013 respectively. It is observed that the built-up areas including bare land/soil have highest temperature and water has the lowest temperature in the three years which is consistent though the values vary. This implies that the temperature in the study is changing drastically which can be attributed to various factors considered in this study most especially land use changes (caused by human activities, urbanization, population growth and others). When the surface experiences increased heat, the land uses in such area are affected and this describes such process aggravating flooding in the catchment.

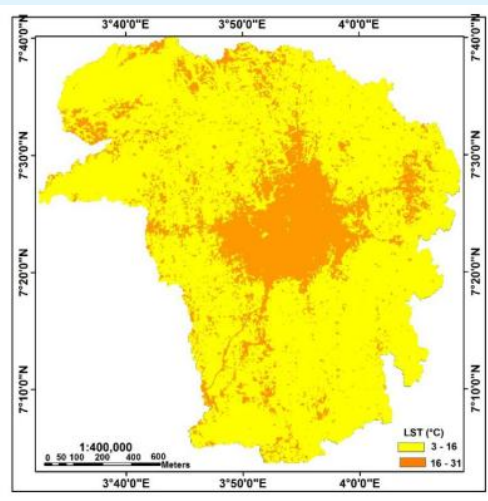

(a)

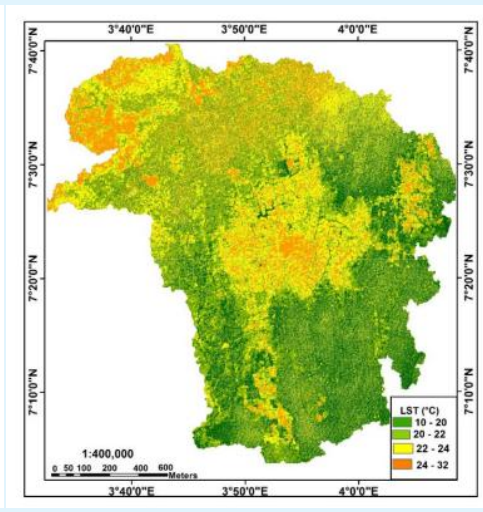

(b)

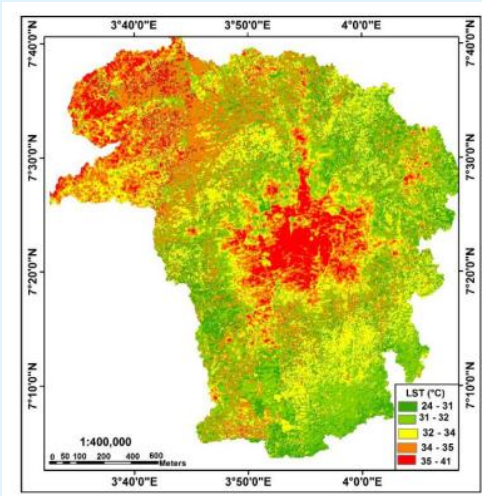

(c)

Figure 2: (a) the derived LST for year 1984 (b) derived LST for year 2000 and (c) derived LST for year 2013. 


\section{Journal of Ecology \& Natural Resources}

\section{Temperature Changes on the Different Land Uses}

The various land uses, and their temperature ranges were further analysed for the period of 27 years (19842013). The amount of temperature in an urban watershed on various land uses tends to contribute the problems of flooding due to the various activities carried out within this watershed. Quantifying the LST of each of the land uses is required in terms of the tendency to increased flooding. This study revealed that the LST range seems moderate for all the land uses while for areas where there exists higher temperature is for built up accounting for 6067 ha $(12.97 \%) 37-41^{\circ} \mathrm{C}$ for the year 2013 as compared to its temperature range in 198416.50 ha $(0.04 \%) 26-28^{\circ} \mathrm{C}$.

Meanwhile, the land use land cover categories like dense vegetation, light vegetation and water tended to have a low range temperature that is increasing but the area reducing as described in figure 9 . The light vegetated areas have a LST values $12-14^{\circ} \mathrm{C}$ covering 90.7 ha and 18$20^{\circ} \mathrm{C}$ covering 0.46 ha for the year 1984 while for the year 2013 the LST of same land use was $28-31^{\circ} \mathrm{C}$ covering 739018.8 ha and $34-37^{\circ} \mathrm{C}$ covering (1276.74 ha). The LST range for built up areas in 2013 is higher when compared with that of 2000 and 1984. This is also attributed to the rate of urbanization and human activities affecting changes on the land uses and this contribute to flood risk in the urban watershed of Ibadan.

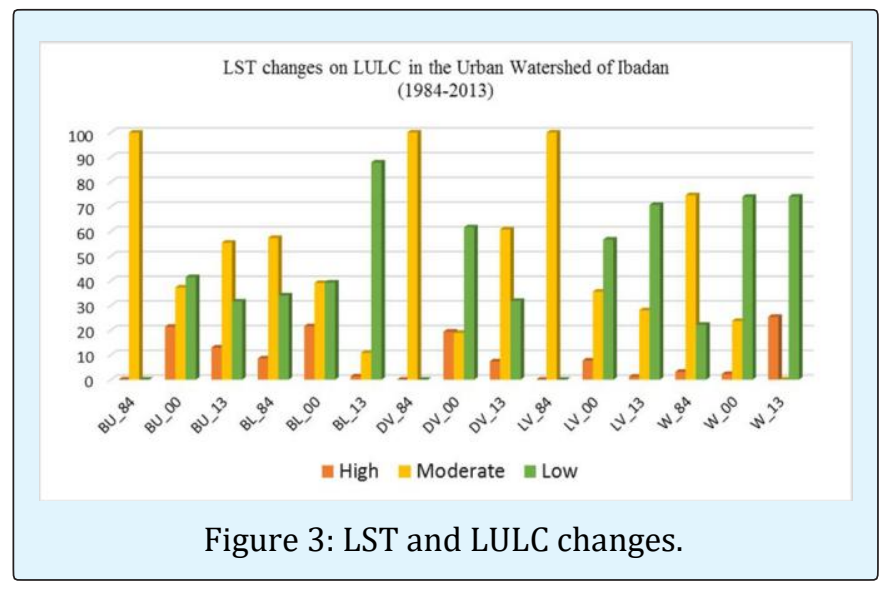

\section{LULCC and Flood Vulnerability}

Further analysis revealed the vulnerable LULCC (Built up, light vegetation, dense vegetation, bare soil /land and water) in each of the sub catchments and categorized into high, moderate and low vulnerable areas. There is a pattern of increase in vulnerability on built up, Light vegetation, bare soil and water body accounting for
8993.60 ha $(94.77 \%), 2364.18$ ha $(9.73 \%), 14121.80$ ha (81.05\%), 419 (77.59) for year 1972 and 26700.57 ha (57.16\%), 9560.65 ha $(9.16 \%), 3697.19$ (83.68), 1.29 ha $(0.78 \%)$ for the year 2013 respectively. Water having moderate vulnerability is accounted to high soil erosion in the upstream and sediments and dissolved substances cumulatively called river load deposited in the river channels and on adjacent flood plains in downstream of the major rivers. All this indicates that the rate of erosion and soil loss in the upstream is high due to lack of abstraction of flood water.

\section{Discussion}

Many factors affect the retrieval of LST from satellite thermal infrared data but some of them, such as transmittance, air moisture, down welling and upwelling radiance, are usually difficult to obtain, especially from satellite observations. In this study, surface emissivity using NDVI was derived and the result agrees with the works of Cresswell MP, et al. [26] which demonstrated its importance in affecting the retrieval of LST from satellite thermal data. The LST range of each of the land uses/ land cover was also analysed which shows the built areas having the maximum LST range and water having the minimum temperature range from (1984-2013). The estimated values over the land use/land cover of Landsat7 TM, Landsat 7 ETM+ and Landsat -8 OLI in the watershed have been compared with Literature values. Zhang, et al. [27] also concluded in his work that from more anthropogenic activities, heat discharge and poor ventilation in the densely built up areas increase the LST. The result shows that the satellite derived emissivity values are in the acceptable range using NDVI and thermal bands of the Landsat imageries are effective in deriving surface emissivity. It also revealed the differences in the LSE and LST among the five classes of land use/cover in the watershed. The implication of these differences in the land use/cover LSTs, is that with increase in urban expansion in the built-up area, vegetation and cultivated land are likely to decline and water body may silt. Theses parameters are remotely sensed surface parameters such as land use land cover, LST, NDVI, IS and host of others. Different scholars have also pointed out that environmental unsound decision made by man has increased or made them more vulnerable to flooding when they build their houses around flood prone areas in urban areas [28] which agrees with findings carried out within the watershed, This urbanization has led to deforestation (forest loss), land use changes, precipitation, temperature modification of soil physical properties and structures and the exposures of bare soil surfaces especially of construction 


\section{Journal of Ecology \& Natural Resources}

sites all of which bring about changes in the morphological and hydrological state of water [29]. All these may likely tamper with the ecosystem services and may result in a phenomenon called the Urban Heat Island and this could increase flood risk in the catchments. This shows that satellite imageries when adequately processed, was more effective in the monitoring of environmental and flood risk parameters for better understanding of environmental issues at both local and regional level and also global change studies [30]. The impacts of decrease in light vegetation and dense vegetation (forest) on landscape in a watershed include increase in run off volumes due to increase in stream channels, road grids and percentage of compacted and impervious surfaces and soils [31,32]. The presence of vegetation cover/ forest canopy in a watershed reduces the amount of run off to streams as vegetation intercepts rainfall and uses it for growth purposes thus impeding overflow of water $[33,34]$. It also plays an important role as a sink for carbon in the atmosphere [35], thus destruction of vegetative cover/forest canopy can increase the level of carbon in the atmosphere, leading to depletion of ozone layer, increase in global temperatures, causing rise in seal level and eventually overflowing of river banks during rainfall that lead to flooding [36-38]. The land use result results of the study area confirm the arguments of these researchers. Manuta and Lebel [38], Olorunfemi [39] and Conservation Ontario [34] have listed the effects of climatic change as it relates to flooding to be: Increase in temperatures could lead to rise in sea levels and is likely to cause intense storms that may impact on flood risks in the area [38]. In a report by WARIMA and START [40], it was mentioned that a $50 \mathrm{~cm}$ rise in sea level in Nigeria will result in permanent inundation of most low lying areas and creation of a new coastline. Variations in rainfall could influence the extent of groundwater recharge, intensity of stream flows and flooding patterns. Extreme thunderstorms that produce large amounts of water in a short timeline are likely to overflow river banks and cause flash floods in the area [41]. Changes in climatic conditions can modify flooding patterns in drainage basins, extending or reducing duration of floods as well as changing timing of seasonal floods [42] thus interrupting any installed flood risk management plans in the region. These changes may produce negative impacts on livelihood and functionality of the system in the area $[43,44]$.

\section{Materials and Methods}

The study was carried out in Ibadan, the capital city of Oyo State located within Latitudes $7^{\circ} 16^{\prime} \mathrm{N}$ and $7^{\circ} 34^{\prime} \mathrm{N}$ and Longitudes $3^{\circ} 44^{\prime} \mathrm{E}$ and $4^{\circ} 02$ ' $\mathrm{E}$. It has a population of $1,338,659$ [45]. It has a tropical wet (lengthy) and dry (short) climate and relatively constant temperatures throughout the course of the year. Ibadan's wet season runs from March through October, November to February forms the city's dry season. The mean total rainfall for Ibadan is $1420.06 \mathrm{~mm}$, falling in approximately 109 days. The city ranges in elevation from $150 \mathrm{~m}$ in the valley area to $237 \mathrm{~m}$ above sea level on the major north-south ridge which crosses the central part of the city. The total area is $1,190 \mathrm{sq}$ mi $\left(3,080 \mathrm{~km}^{2}\right)$. The city is naturally drained by four rivers with many tributaries: Ona River in the North and West; Ogbere River towards the East; Ogunpa River flowing through the city and Kudeti River in the Central part of the metropolis [46]. Most areas of the city are covered by rainforest and derived savanna.

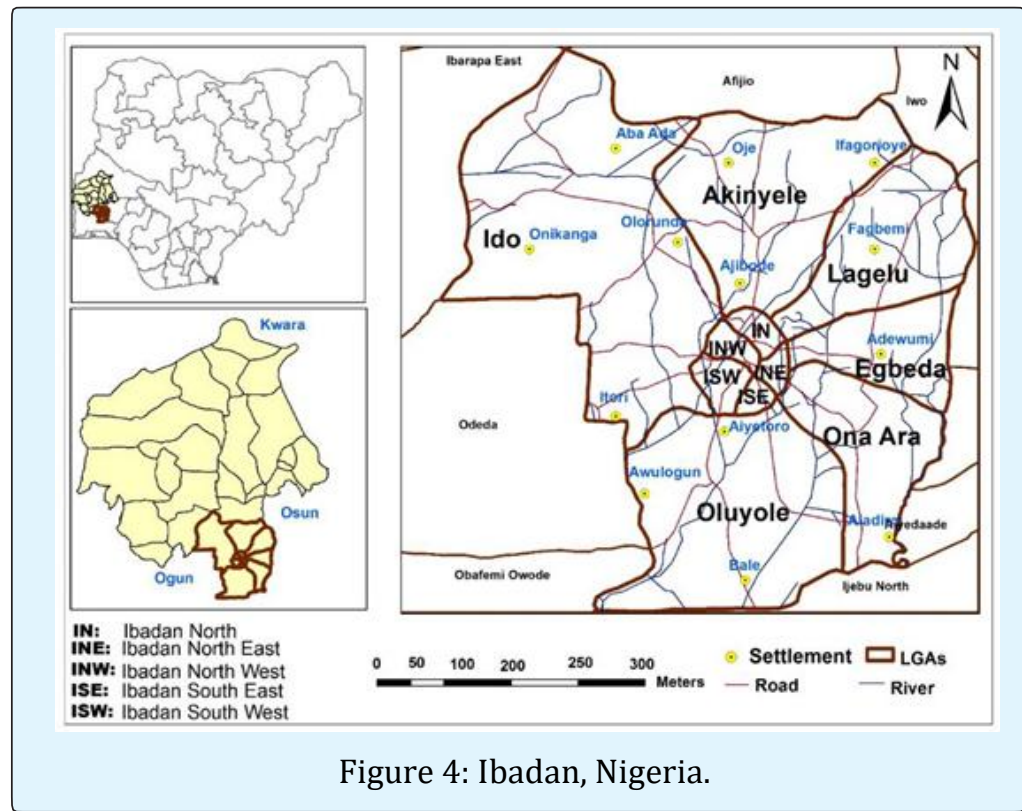

Adetoro 0 and Salami A. Assessment of Land Surface Temperature and LULC Changes and the Antecedent Flood Hazard in Ibadan, Nigeria. J Ecol \& Nat Resour 2018, 2(2): 125. 


\section{Journal of Ecology \& Natural Resources}

\section{Data Types and Sources}

Primary data: GPS receiver was used to obtain the geographic coordinates of features under study.

Secondary data: This includes satellite imageries, topographic maps and soil map. Multi Spectral Scanner (MSS) (4Bands), Thematic Mapper (TM) (7 bands), Enhanced Thematic Mapper (ETM) (7 Bands) and Landsat 8 Operational Land Imager (OLI) (12 bands) spectral band satellite imageries (Path 191, Row 55) for the year $2013,2000,1984$ with a spatial resolution of $30 \mathrm{~m}$ and 1972 with a spatial resolution of $28 \mathrm{~m}$ but was resampled to $30 \mathrm{~m}$. These were used for estimating the Land use/Land cover dynamics of the area and for deriving the land surface temperature.

Topographic maps covering the area extent of Ibadan was used to extract the river (drainage networks), topological features, place names, settlements, roads, contours and vegetation types amongst others. The soil map was also acquired for extracting information about the various types of soils, composition and drainage/infiltration property using literatures and field survey/observations to aid the flood vulnerability analysis. Also, a slope and elevation map was generated using ASTERDEM.

\section{Data Analysis}

The Landsat satellite imagery was pre-processed for accurate change analysis and detection which includes geometric correction. In estimating the land surface temperature, the thermal infrared band (band 6) is the choice band for estimating surface temperature because radiation emitted from the earth surfaces in the form of heat ranges between 3.0 to $100 \mu \mathrm{m}[25,47-50]$ and the Band 10 which is the thermal band of OLI and is not being utilized presently for such purpose. The present study analyses the potential of LST estimation using the three Landsat of different years namely; TM, ETM+ and OLI over the catchment area.

The Thermal bands for each of the images were considered. The study considers variation of LST over different LU/LC over a period of twenty-nine (29) years.

The temperature corresponding to a black body radiator emitting the same radiance is called the brightness temperature. To derive this, the derived Top Atmospheric Reflectance (ToAr) was used with other parameters.

$$
\begin{array}{r}
\mathrm{T}=\mathrm{K} 2 \\
\text { In }[\mathrm{K} 1 / \mathrm{L} \lambda+1]
\end{array}
$$

Where;

$\mathrm{T}=$ ToA Brightness Temp

$\mathrm{L} \lambda=$ ToA_Sprectral Radiance

Where K1 and K2 are" constants chosen to optimize the approximation for the band pass of the sensor. The values for gotten form the data used for the study.

$\mathrm{K} 1=774.89$

$\mathrm{K} 2=1321.08$

[Temp_ Band" X".tif $=1321.08 / \mathrm{In}$ [[774.89/ToA_Radiance] +1] Year 2013

The same procedure is applicable to year 2000 and 1984 but differs with values for estimation of LST, derivation of surface emissivity is important. The surface emissivity maps were produced from five broad land covers namely dense vegetation/forest, light vegetation/shrubland, urban/semi urban, Water and bare land/soil.

The surface emissivity is estimated by using NDVI and an empirically-derived method [51]. Using equation 2 . The landuse landcover was reclassified using the different emissivity values generated [51]

$$
=1.009+0.047 \text { (InNDVI) NDVI }>0
$$

For NDVI $<0$ (e.g water) emissivity of 1 was estimated Conversion from ToA Brightness temperature/At-Surface Temperature to Land

Surface Temperature

$$
\mathrm{T}=\mathrm{TB} /[1+(\lambda * \mathrm{~TB} / \mathrm{P}) \operatorname{In} \sigma
$$

Where;

$\mathrm{P}=\mathrm{h}^{*} \mathrm{c} / \sigma\left(1.438^{*} 10 \Lambda 2 \mathrm{mk}\right)$

$\mathrm{h}=$ (planks constant $(6.626 * 10 \Lambda 34 \mathrm{js})$

$\sigma=$ Bottzman Constant $(1.38 * 10 \Lambda-23 \mathrm{jk})$

$\mathrm{c}=$ Velocity of light $(2,998 * 10 \Lambda 8 \mathrm{~m} / \mathrm{s})$

$\mathrm{a}=$ Emissivity

$\mathrm{TB} / \mathrm{b}=$ Brightness Temperature

$\mathrm{T}=(\mathrm{b} /(1+(10.8 * \mathrm{~b} / 14380) * \operatorname{In}[(\mathrm{a})]) \quad$ Year 2013

This equation was also adopted for the year 2000 and 1984 but their values differ from one another.

Conversion of Land Surface Temperature from Kelvin to Celsius was done by:

Celsius $=\mathrm{T}-273.15$ which was applied for all the years

Change Detection/Trends of LULC Change

Post-classification methods: Post classification comparison method was used for change detection. This method has the capability of providing a matrix of change 


\section{Journal of Ecology \& Natural Resources}

information and reducing external impact from atmospheric and environmental differences between the multi-temporal images [52-54].

Nature, Extent and Rate of Change: To determine the extent and rate of change in the land cover dynamics in the region, the following variables are developed and computed as described

- Total area (Ta)

- Changed area (Ca)

- Change extent (Ce)

- Annual rate of change $(\mathrm{Cr})$

These variables can be described by the following formula:

$\mathrm{Ca}=\mathrm{Ta}(\mathrm{t} 2)-\mathrm{Ta}(\mathrm{t} 1)$;

$\mathrm{Ce}=\mathrm{Ca} / \mathrm{Ta}(\mathrm{t} 1)$;

$\mathrm{Cr}=\mathrm{Ce} /(\mathrm{t} 2-\mathrm{t} 1)$; Where $\mathrm{t} 1$ and $\mathrm{t} 2$ are the beginning and ending time of the land cover studies conducted.

+ve Value indicates a progression of class area while -ve Value indicates regression of class area as described by Toyi MS, et al. [54].

The change analysis panel provides a rapid quantitative assessment of change by graphing gains and losses by land cover categorizes. A second option, net change shows the result of taking the earlier land cover areas, adding the gains and then subtracting the losses. The third option is to examine the contributions to changes experienced by single land cover. The change rate analysis was performed between three pairs of images of 1973/1984, 1984/2000 and $2000 / 2013$. The transition changes were obtained in map and graphical form. All units were changed to hectares and percentages.

The NDVI classified was further analysed to know and present changes that has occurred from 1984 -2013.

The land use/land cover with the land surface temperature ranges in minimum and maximum was analysed and plotted to show the LULC with the highest and the lowest and to know the changes that have occurred from 1984 -2013. The analysis involves knowing the extent, trend and rate of change in the urban watershed.

\section{Conclusions}

This study affirmed that the integrated approach was effective in assessing flood hazard causative factors and the components of flood vulnerability and risk. The change statistics of land use/land cover of urban watershed of Ibadan and the increasing temperature showed that clearance of land cover for urban expansion has been aggravating flood hazard in the downstream areas of the urban watershed. Although the amount of research available for studying flood risk using all potential scenarios in watershed is improving as of late such as different automated impervious surface mapping and estimating land surface temperature, however, there is need to develop techniques that will result in increased accuracy in automated impervious surface and surface temperature acquisition.

\section{References}

1. Parker DJ (2000) Floods London and New York: Routledge.

2. Odufuwa BO, Adedeji $\mathrm{OH}$, Oladesu JO, Bongwa A (2012) Floods of Fury in Nigeria Cities. J Sustainable Development 5(7).

3. Aderogba KA (2012) Global Warming and Challenges of Flood in Lagos Metropolis, Nigeria. Academic Research International 2(1): 448-468.

4. Adeaga $O$ (2000) Flood Hazard Mapping and Risk Management in parts of Lagos Akoka NE; Department of Geography Faculty of Environmental Sciences, University of Lagos.

5. Amori AA, Awomeso JA, Idowu OA, Makinde AA (2012) Differentials in Public Perception of Urban Flood Control and Management Measures along Ogunpa River,South-west, Nigeria. J Safety Engineering 1(3): 39-42.

6. Nirupama N, Simonovic S (2004) Is Urbanization Increasing Risk? Ontario: Ontario Assessment Ecclectica.

7. Smith K (1996) Environmental Hazards. London: Routledge.

8. Akintola FO (2004) Sustainability Issues in Flood Management in Nigeria. In: Ivbijjaro MF, and Akintola FO, Sustainable Environmental Management in Nigeria. Ibadan: mattivi productions, pp: 105-116.

9. Baiye E (1988) Human in the Throes of Floods. pp: 9.

10. Akinyemi FO (2013) An Assessment of Land-Use Change in the Cocoa Belt of South -West Nigeria. International J Remote Sensing 34(8): 2858-2875.

11. Nwaubani C (1991) Ogunpa River Leaves Bitter Aftertaste in Tragic Course Through Abeokuta. Lagos: The Guardian. 
12. Edward- Adebiyi R (1997) The Story of Ogunpa. In: The Guardian, pp: 5

13. Jeb DN, Aggarwal SP (2008) Flood Inundation Hazard Modeling of the River Kaduna Using Remote Sensing and Geographic Information System. J Applied Sci Res 4(12): 1822-1833.

14. Ikuhoria I, Yesuf GU, Enaruvbe GO, Ige-Olumide 00 (2012) Assessment of the Impact of Flooding on Farming Communities in Nigeria: A Case Study of Lokoja, Kogi State Nigeria. Geospatial Technologies and Digital Cartography, Proceedings of Joint Conference of Geoinformation Society of Nigeria and Nigerian Cartographic Association, pp: 174-185.

15. Abbas II (2008) Use of Satellite Remote Sensing and Geographic Information System to Monitor Land Degradation along Ondo Coastal Zone (Nigeria). Ohrid Republic of Macedonai: BALWOIS.

16. Hao Z, Wei-chun M, Xiang-rong W (2008) Rapid Urbanization and Implication for Flood Risk Management in Hinterland of the Pearl River Delta, China: The Foshan study. Sensors 8(4): 2223-2239.

17. Melesse AM (2004) Spatiotemporal Dynamics of Land Surface Parameters in the Red River of the North Basin. Physics and Chemistry of the Earth 29(11-12): 795-810.

18. Taiwo 0 (2008) 'Flood Sacks 500 in Babura' in this day. 13(4867): 18.

19. Amaize E (2011) Flood displaces 50 Villagers in Delta State, in Vanguard: Towards a better life for the people. Lagos: Vanguard Media Limited, pp: 9.

20. Babalola JS (1997) The June 24th 1995 Flood in Ondo: Its Antecedents and Incidents. Ife Research Publications in Geography 6: 158-164.

21. Atdhor OA, Odjugo PAO, Uriri A (2011) Changing Rainfall and Anthropogenic Induced Flooding: Impacts and Adaptation Strategies in Benin City, Nigeria. J Geography and Regional Planning 4(1): 4252.

22. Mordi R (2011) The Tsunami in the making. The Tell: Nigerian Independent Weekly. Lagos: Tell Communications Limited, pp: 5463.

23. Aderogba KA (2012) Qualitative Studies of Recent Floods and Sustainable Growth and Development of
Cities and Towns in Nigeria. International J Basic Applied Sciences 1(2): 2.

24. Schmugge T, Hook SJ, Coll C (1998) Recovering Surface Temperature and Emmisitivity from Thermal Infra-Red Multispectral Data. Remote Sensing of Environment 65(2): 121-131.

25. Cresswell MP, Morse AP, Thomson MC, Connor SJ (1999) Estimating surface air temperatures, from Meteosat land surface temperatures, using an empirical solar zenith angle model. Inter J Remote Sensing 20(6): 1125-1132.

26. Zhang J, Chenghu Z, Xu K, Watanabe M (2002) Flood Disaster Monitoring and Evaluation in China. Environmental Hazards 4(2-3): 33-43.

27. Bryant EA (1991) Natural hazards, Cambridge University Press, United Kingdom.

28. Ebisemiju FS (1993) Environmental Hazards. In F. S. Ebisemiju, Ado -Ekiti Region: A Geographic Analysis and Master Plan. Ado Ekiti: Alpha Prints.

29. Ifatimehin 00 (2007) Estimating Surface Temperature of Lokoja Town Using Geoinfomatic Technology. International Journal of Ecology and Environmental Dynamics, 4.

30. Capital Region Watershed District (CRWD) (2004) Examples of Alternatives, Permeable Surfaces.

31. Ajibade LT, Ifabiyi IP, Iroye KA, Ogunteru S (2010) "Morphometric analysis of Ogunpa and Ogbere drainage basins, Ibadan, Nigeria". Ethiopian J Environ Studies and Management 3(1): 13-19.

32. Calder IR (1993) Hydrologic effects of land-use change. Chapter 13 in Maidment, D. R., Handbook of hydrology. McGraw-Hill, New York, pp: 50.

33. Conservation Ontario (2001) The Importance of Watershed Management in Protecting Ontario's Drinking Water Supplies.

34. Ujoh F, Kwabe ID, Ifatimehin 00 (2011) Urban expansion and vegetal cover loss in And around Nigeria's Federal Capital City. J Eco Nat Environ 3(1): $1-10$.

35. Kasali MA (2011) Climate and intercultural crisis: climate change as a source of interreligious violence in Kano, Nigeria. J Sustainable Development in Africa 13(4): 96-109. 
36. Hodo IO (2011) A GIS-Based Flood Risk Mapping of Kano City, Nigeria. An unpublished Thesis, School of Environmental Sciences University of East Anglia University Plain, Norwich.

37. Manuta J, Lebel L (2005) Climate change and the risks of flood disasters in Asia: crafting adaptive and just institutions. Human Security and Climate Change, An International Workshop organised by Global Environment and Security project (GECHS), near Oslo, 21-23.

38. United Nations International Strategy for Disaster Reduction (UNISDR) (2002) Guidelines for Reducing Flood Losses.

39. West African Research and Innovation Management Association (WARIMA) and START International Secretariat (2010) Integrating Climate Change Adaptation and Mitigation in Development Planning: National Policy Dialogue in Nigeria, Post Dialogue Report, the Postgraduate School, and University of Ibadan, Nigeria.

40. Brezger A (2004) Land Use Forecasting and Natural hazards: Current and Future Impacts of Flooding in Urban Areas: A Case Study of Pordenone Province. Italy: Friuli-Venezia Giulia (FVG).

41. Coburn AW, Spence RJ, Pomonis A (1994) A vulnerability and risk assessment, $2^{\text {nd }}$ (Edn.), United Nations Development Programme (UNPD).

42. Brooks N (2003) Vulnerability, Risk and Adaptation: A conceptual Framework. Tyndal Centre for Climate Research.

43. Olorunfemi FB (2011) Managing Floods Disasters under a Changing Climate: Lessons from Nigeria and South Africa. Nigeria Institute of Social and Economic Research 1(1): 1-44.

44. National Population Commission (2006) National Population Census. Federal Republic of Nigeria Official Gazette 96(2).

45. Akintola FO (1994) Flooding Phenomenon in Ibadan Region. Ibadan: Rex Charles Publication and Comel Publications.
46. Carnahan WH, Larson RC (1990) An Analysis of an Urban Heat Sink. Remote Sensing of Environment 33(1): 65-71.

47. Nichol JE (1994) A GIS Based Approach to Microclimate Monitoring in Singapore's High-Rise Housing Estates. Photogrammetric Engineering and Remote Sensing 60(10): 1225-1232.

48. Weng Q (2001) A remote sensing GIS Evaluation of Urban Expansion and its Impacts on Surface Temperature in the Zhujiangn Delta, china. International Journal of Remote Sensing 22(10): 1999-2014.

49. Weng Q Lu D, Schubring J (2004) Estimation of Land Surface Temperature-Vegetation and Abundance Relationship for Urban Heat Island Studies. Remote Sensing of Environment 89(4): 467-483.

50. Niehol JE (1996) High-resolution surface temperature patterns related to urban morphology in a tropical city, a satellite- based study. J applied meteology 35: 135-146.

51. Environmental Protection Agency (EPA) (1999) Level 111 Ecoregions of the Continental United States, U.S. Environmental Protection Agency, National Health and Environmental Effects Research Laboratory, Corvallis, Oregon.

52. Lu D, Weng Q (2004) Spectral Mixture Analysis of the Urban Landscape in Indianapolis with Landsat ETM+ imageries. Photogrammetric Engineering and Remote Sensing 70, 1053-1062. Research 4(12): 1822-1833.

53. Mundia CN, Aniya M (2005) Assessment of Land use/cover changes and urban expansion of Nairobi city using remote sensing and GIS. Inter J Remote Sensing 26(13): 2831-2849.

54. Toyi MS, Barima Y S, Mama A, André M, Bastin JF, et al. (2013) Tree Plantation will not Compensate Natural Woody Vegetation Cover Loss in the Atlantic Department of Southern Benin. Tropicultural 1: 6270.

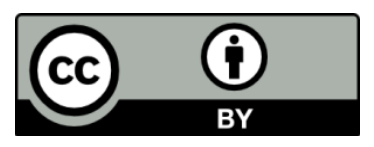

